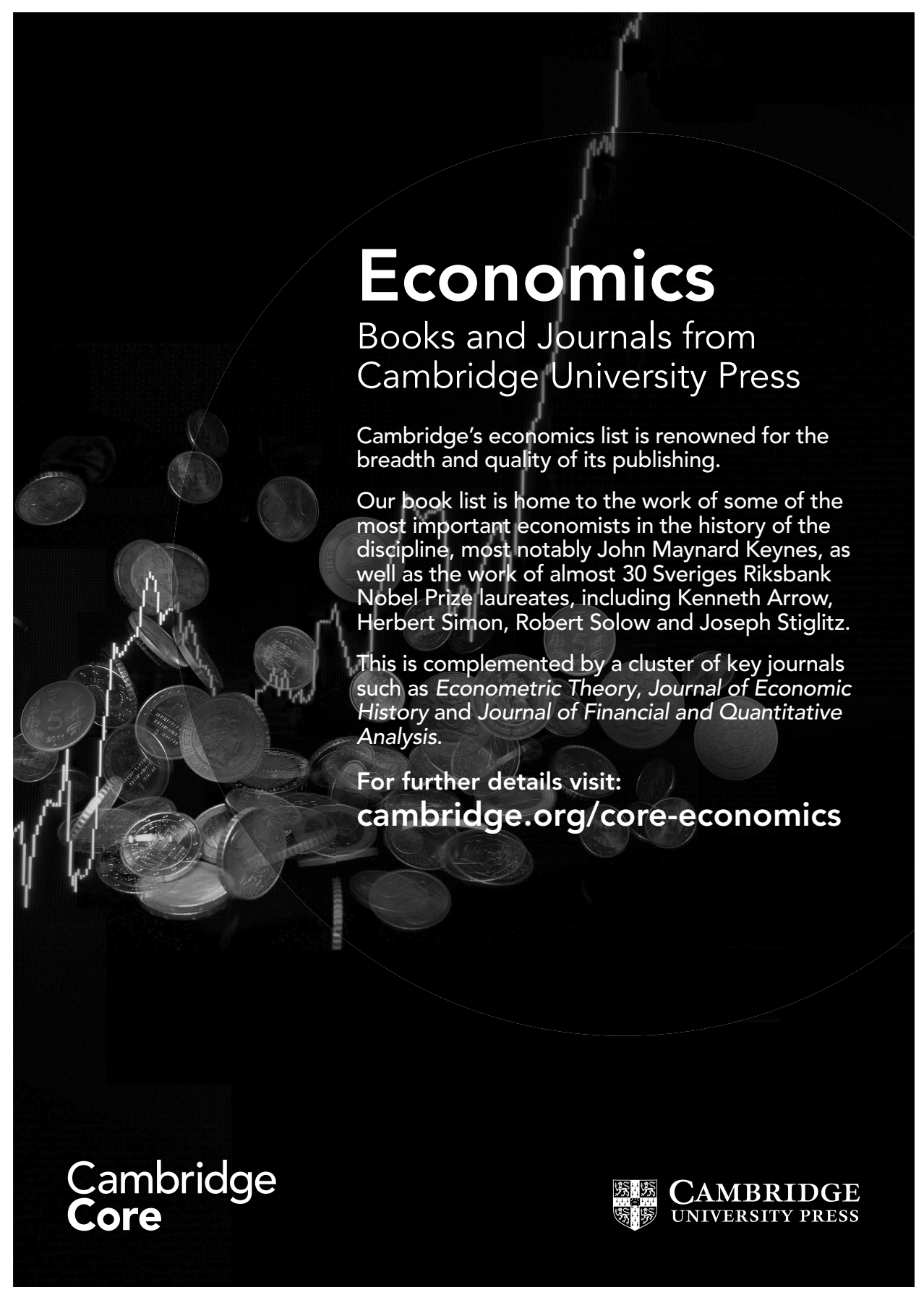




\section{Notes for Contributors}

All manuscripts should be submitted via our on-line system, ScholarOne Manuscripts at: http://mc.manuscriptcentral.com/jode Other forms of submission will not be accepted by the editors. Articles submitted to the Journal should be original contributions. They should not be under consideration by another journal, nor have been published or be awaiting publication elsewhere. Submission should have been approved by all co-authors.

Replication Policy: On acceptance of their paper, authors must submit a complete set of any data used in the paper. Computer code necessary to run a commercial program or the source code of a non-commercial program must also be submitted. The results of the paper must be capable of replication given access to any commercial program used to obtain the results. The data, computer programs, and code will be maintained in the data archive which is linked to the journal's homepage.

Authors are responsible for obtaining permission to reproduce any material they do not own the copyright for and for ensuring appropriate acknowledgment of such material.

All manuscripts should follow the manuscript preparation guidelines available online in the full instructions for contributors.

Full Instructions for Contributors can be found online at cambridge.org/dem/ifc

\section{Rights and Permissions info}

All rights reserved. No part of this publication may be reproduced, stored or transmitted in any form or by any means without the prior permission in writing from the copyright holder. This journal is registered with the Copyright Clearance Center, 222 Rosewood Drive, Danvers, MA 01923, USA. Organizations in the USA who are also registered with the C.C.C. may, therefore copy material (beyond the limits permitted by, sections 107 and 108 of U.S. Copyright law) subject to payment to the C.C.C. of the appropriate fee per copy. This consent does not extend to multiple copying for promotional or commercial purposes.

For all other use, permission should be sought from Cambridge or the American Branch of Cambridge University Press.

\section{Subscriptions}

Journal of Demographic Economics is published four times a year in March, June, September and December. The 2018 subscription price (excluding VAT) of a volume, which includes print and electronic access, is $£ 310.00$ (US $\$ 411.00$ in USA, Canada and Mexico); $£ 39.00$ (US \$56.00) for individuals, which includes print and electronic access, ordering direct from the publishers and certifying that the journal is for their personal use. The electronic-only price available to institutional subscribers is $£ 268.00$ (US $\$ 360.00$ in USA, Canada and Mexico). EU subscribers (outside the UK) who are not registered for VAT should add VAT at their country's rate. VAT registered subscribers should provide their VAT registration number. Prices include delivery by air when appropriate. Japanese prices for institutions are available from Kinokuniya Company Ltd, P.O. Box 55, Chitose, Tokyo 156, Japan. Orders, which must be accompanied by payment, may be sent to a bookseller, subscription agent or direct to the publisher: Cambridge University Press, Journals Fulfillment Department, UPH, Shaftesbury Road, Cambridge CB2 8BS, UK; or in the USA, Canada and Mexico: Cambridge University Press, 1 Liberty Plaza, Floor 20, New York, NY 10006, USA. Periodicals postage paid at New York, NY and additional mailing offices.

Printed in the United Kingdom by Bell and Bain Limited, Glasgow

This journal issue has been printed on FSC(TM)-certified paper and cover board. FSC is an independent, non-governmental, non-for-profit organization established to promote the responsible management of the world's forests. Please see www.fsc.org for information. 


\section{JOURNAL OF \\ DEMOGRAPHIC ECONOMICS}

\section{Research Papers}

Terry-Ann Craigie, Samuel L. Myers, Jr. and William A. Darity, Jr. Racial Differences in the Effect of Marriageable Males on Female Family Headship

\section{Kellie Forrester and Jennifer Klein An}

Analysis of Female Labor Supply, Home Production, and Household Consumption Expenditures

Frank R. Lichtenberg The Impact of New Drug Launches on Life-Years Lost in 2015 From 19 Types of Cancer in 36 Countries
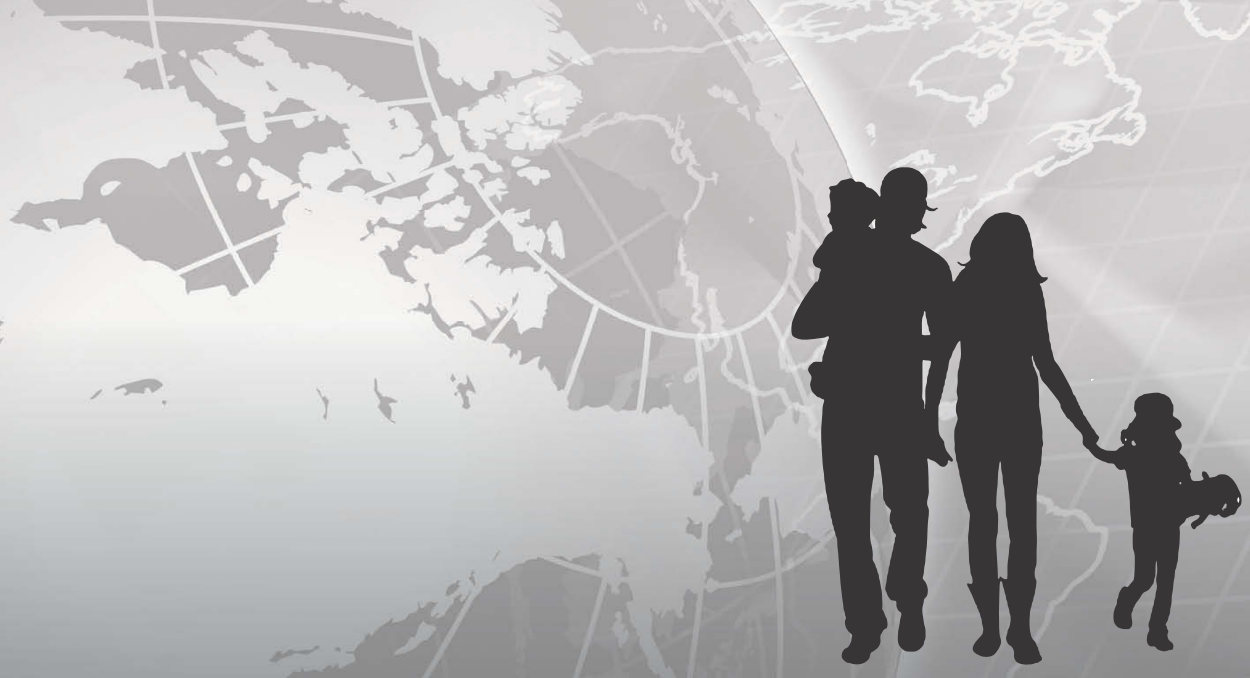

\section{Cambridge Core}

